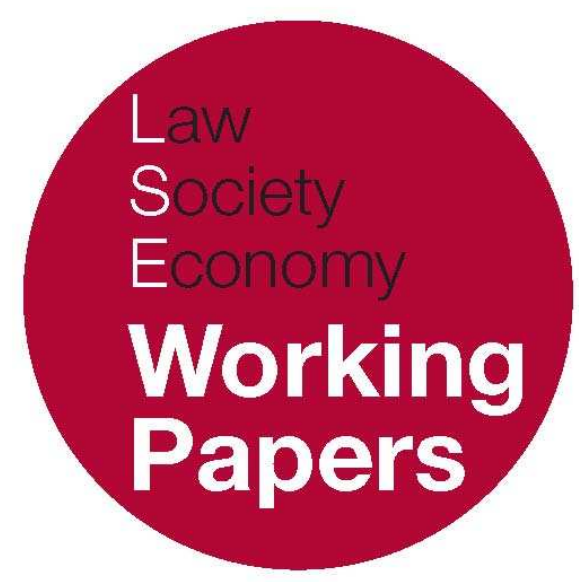

\title{
Escaping Hobbes: Liberty and Security for Our Democratic (Not Anti-Terrorist) Age
}

\author{
Conor Gearty \\ LSE Law, Society and Economy Working Papers 3/2010 \\ London School of Economics and Political Science \\ Law Department
}

\begin{abstract}
This paper can be downloaded without charge from LSE Law, Society and Economy Working Papers at: www.lse.ac.uk/collections/law/wps/wps.htm and the Social Sciences Research Network electronic library at: http://ssrn.com/abstract=1543121.

(C) Conor Gearty. Users may download and/or print one copy to facilitate their private study or for non-commercial research. Users may not engage in further distribution of this material or use it for any profit-making activities or any other form of commercial gain.
\end{abstract}




\title{
Escaping Hobbes: Liberty and Security for Our Democratic (Not Anti-Terrorist) Age
}

\author{
Conor Gearty *
}

\begin{abstract}
The terms 'liberty' and 'security' are analysed against a background of contemporary concerns about terrorism and the decline of freedom. The influence of Hobbes's approach to liberty has been pervasive, and the effect of this has been to promote an approach to freedom which has been too willing to sacrifice individual liberty to the needs of the state. Republican attitudes to freedom have been likewise disinclined to allow the individual to get in the way of what the exigencies of the moment demand. The result of these two large-scale and important sets of historical ideas has been a democratic polity (in Britain and the US, but across the world, as well), which has been too consumed with (national) security and not sufficiently alive to the demands either of a broader kind of human security rooted in human flourishing or to the political liberty necessary to its achievement. The essay argues for a new reconciliation between liberty and security based on the language of human rights and manifested in, firstly, a wider approach to security (encompassing social and economic rights) and, secondly, a renewed commitment to the criminal law as the best means available for squaring security from harm with an unequivocal respect for the person, which must always be at the core of any human rights framework.
\end{abstract}

\footnotetext{
* Law Department, London School of Economics and Political Science, Professor of human rights law. I am grateful to colleagues at two talks I gave at SOAS and in LSE for their very helpful input into the ideas developed in this essay. In particular, I'd like to thank Alasdair Cochrane, Phil Cook, Neil Duxbury, Steve Hopgood, Paul Kelly, Chandran Kukathas, Annabel Lever, Emmanuel Melissaris, Tom Poole, Peter Ramsay, Mike Redmayne, and Leslie Vinjamuri for their helpful comments and general support.
} 


\section{INTRODUCTION}

There are few words more dangerously confusing in their meaning than 'liberty' and 'security'. The first has a range which takes it across a spectrum from the essence of human freedom at one end to a far narrower statement about the need for unrestrained movement at the other. Liberty is sometimes thought of as concerned with the individual qua individual and on other occasions with the individual within society: at one moment the word seems to about the need to be left alone by all authority, while at the next it positively suggests active participation in the government of the state. No one seems quite sure whether 'liberty' is - in any of its incarnations - the same as 'civil liberties', and even if it is, there are, as Jeremy Waldron has pointed out, at least four separate meanings to the latter term. ${ }^{1}$ As for the lawyers, in pre-rights days they got into the habit of thinking of 'civil liberties' as primarily concerned with the law on the control of police powers, and this is a space that the subject still occupies in practice. ${ }^{2}$

The term 'security' has a similar range and equivalent levels of vagueness. Used in conjunction with liberty, security has historically been taken to refer to 'national' security, to the protection from external and perhaps even internal threat of particular lands organised as states. ${ }^{3}$ The field of counter-terrorism has grown out of this orientation of security towards protection from attack. Taking a different tack, we now also see the idea of security being reconfigured for the global age as 'human security' - an idea of protection that focuses on people not places, and which tries to get beyond immediate attacks on freedom to systemic failures in the public sphere that render us all (in a broader sense) less secure. ${ }^{4}$ Lurking in the background is the idea of security as a guarantor of well-being, captured in a contemporary term, 'social security', now so familiar to us that we have forgotten the startling idealism and ambition that once oozed from these two words.

Both terms 'liberty' and 'security' have been at the forefront of political discussion in recent years; perhaps clarification of the main sense in which the words are used today can be found there? The British Prime Minister Gordon Brown is very interested in liberty and has made speeches about it on a number of occasions since he assumed the premiership, but it is fair to say that he has hedged his bets when it has come to close analysis of the term. It is 'rooted in the human spirit and does not have a nationality', while at the same time having a 'distinctly

\footnotetext{
${ }^{1}$ J. Waldron, 'Security and Liberty: The Image of Balance' (2003) 11 Journal of Political Philosophy 191, 195. 2 See for example, R. Clayton, H. Tomlinson, E. Buckett, and A. Davies, Civil Actions Against the Police (London: Sweet and Maxwell, 3rd ed, 2005).

${ }^{3}$ See for example, the remit adopted by the Institute of Public Policy Research, Shared Destinies. Security in a Globalised World. The Interim Report of the IPPR Commission on National Security in the 21st Century (London: 2008).

4 There is a good account of the rise of the term in G. Oberleitner, 'Porcupines in Love: The Intricate Convergence of Human Security and Human Rights' in A. Melbourn and G. Gunner (eds), Human Rights - From the Frontiers of Research (Stockholm: Justus Förlag, 2005).
} 
British interpretation - one that asserts the importance of freedom from prejudice, of rights to privacy, and of limits to the scope of arbitrary state power... ${ }^{5}$ Liberty demands 'that the realm of individual freedom encompasses not just some but all of us' and so emphatically rejects 'the selfishness of extreme libertarianism.' ${ }^{\prime}$ Its historical roots in Britain reflect 'a struggle for tolerance' which involves both an important 'right to dissent' and a more recent, internationalist move towards respect for 'the right of everyone - human rights'. 7 There is so much work here for liberty to do that the word could be forgiven for shrugging its shoulders and adapting itself to whatever is entailed in the latest demand made of it by the Prime Minister.

Perhaps this is why it has not been able to do much to withstand the crystal clarity of the meaning that Mr Brown has chosen to ascribe to 'security'. The 'modern security challenge is defined by new and unprecedented threats: terrorism; global organised crime; organised drug trafficking and people trafficking. This is the new world in which government must work out how it best discharges its duty to protect people'. ${ }^{8}$ Extended detention before charge, greatly expanded police powers, anti-terrorism control orders, and so on are necessitated by the exigencies of a security situation which demands strong action, even from (perhaps especially from) a Prime Minister who believes himself to be deeply committed to liberty. There is no perceived contradiction between the two - the generality of the claims made on behalf of liberty have lifted it into an ethical realm so rarefied that it requires little contact with real life decision-making in order to stay alive (even to flourish as a consolatory piece of internal rhetoric) in the minds of its proponents.

Danger lies not so much in the confusion as such (inelegant though it is), but in the freedom of action for power that vagueness permits. If words mean all things to all, then what matters is who has the power to turn their words into action, into people being locked up or put under house arrest, into police action or state forbearance in the name of freedom. This is exemplified by the way in which President G. W. Bush felt able, without any sense of self-mockery or irony, to devote his second inaugural address, in January 2005, almost entirely to liberty, to an America which 'proclaims liberty throughout all the world' and to the conviction that ' $[\mathrm{i}] \mathrm{n}$ the long run, there is no justice without freedom, and there can be no human rights without human liberty." The mystery here is as to how such an avowed partisan of liberty could at exactly the same time be engaged in both creating truly large-scale frameworks for the deprivation of the liberty of so many (Guantanamo and the other camps for those detained in Iraq and Afghanistan) and also in authorising executive actions (coercive interrogation;

\footnotetext{
${ }^{5}$ Speech on liberty by the prime minister 29 October 2007:

see $<$ http://www.number10.gov.uk/Page13646 $>$ (last visited 30 November 2009).

6 ibid.

7 ibid.

${ }^{8}$ Speech on security and liberty, 17 June 2008: see < http://www.number10.gov.uk/Page15785> (last visited 30 November 2009).

${ }_{9}^{9}$ See $<$ www.npr.org/templates/story/story.php?storyId=4460172> (last visited 30 November 2009).
} 
extra-statutory wire-tapping) which are highly invasive of liberty in a broader meaning of the term. Despite this (it might be thought) obvious point, there was no sense during the Bush presidency of a man in high office gnashing his teeth and anxiously wondering whether he was being contradictory, or even of a commander-in-chief reluctantly allowing exceptions to his freedom-agenda in narrowly defined sets of circumstances. Right to the end, Bush held fast to the belief that he had been a servant of freedom. ${ }^{10}$ As with Mr Brown, there is no trade-off here - rather a distinct kind of fit, not dependant on rendering the term vacuous as (it might be unkindly remarked) is the case with Brown, but rather on (as we shall see) rooting the notion of liberty in a particular set of American (but nevertheless purportedly and not non-nonsensically universalisable) values.

In this paper, towards the end, I will argue for a particular version of 'liberty' and 'security', one in which the two terms coalesce together by drawing on a set of benign threads in our human history - benign in the robust sense of having delivered to us today much of what we value and see as civilised in the world around us. This will not be the perspective promoted by Mr Bush, but nor will it be the 'all things to all people' approach favoured by Mr Brown. To give my argument a chance of being effective, however, it is necessary as a preliminary matter, first to seek to rescue the two terms from the confusion which has just been described and from the false fit to which that confusion has given rise. As a first stop on this road to a new synthesis of liberty and security, I will be arguing that while the Brown analysis is largely incoherent, the Bush approach reflects a dangerous blending of our two terms, one that has done damage to what I say are the progressive qualities which ought to be inherent in the term 'liberty', while at the same time contriving to maroon 'security' in the cul-de-sac of crime prevention and counter-terrorism. This malign complementary (as I shall call it) has its roots in history, but in contradistinction to my benign synthesis (on which, as I say more later) the landmarks it has scattered across our past are creatures of reaction, not of social growth. The first three sections of the paper are concerned with this defective symbiosis between liberty and security - the original synthesis between the two; its impact during the democratic era; and then the exacerbating effect of the politico-legal reaction to the attacks of 11 September 2001. Only then will it be possible to end on the high note (at least I hope it is a high note) of my alternative approach.

Our first stop is an enquiry into the origins of the uncertainty described above. This task takes us, as is so often the case with Anglo-American political foundations, on a journey back into the 1640s, and to the turmoil of the English

10 Though interestingly, while not being disavowed, the freedom-agenda played only a very small part in Mr Bush's reflections in the course of his final session as president with the press, and then only in the context of the reputation abroad of the US: see <www.foxnews.com/politics/2009/01/12/raw-datatranscript-bushs-white-house-press-conference/> (last visited 23 January 2009, not now available; see further < http://www.america.gov/st/texttrans-english/2009/January/20090112141227eaifas8.796328e$\underline{\text { 02.html\&distid }=\text { ucs }}>$ (last visited 30 November 2009). 
civil wars from which so much else has flowed, not least important fragments of how we use words like 'liberty' and 'security' today. The various threads to meaning that emerged then endure today and understanding them helps to explain how such radically different positions as we have identified above can be adopted by those who nevertheless say they share a common allegiance to liberty. During these vital years, a brilliant apologist for royal power grabbed hold of the idea of 'liberty' - the most progressive term in the vocabulary of the radicals of the day and by dint of a phony divide with 'security' turned it from an engine of freedom into a rationale for servitude. Thomas Hobbes may not have been the first servant of power to distort progressive terms to suit his masters, and we know, from the second gulf war and various human rights arguments for lesser evils and so on that we are forced to suffer today, that he was by no means the last. But he is the most important. So this enquiry must start with the Latimer school's star pupil, later one of Oxford's most famous graduates and in early adulthood a man who earned his bread as the sometimes teacher and afterwards general intellectual factotum of the second Earl of Devonshire. ${ }^{11}$

\section{LIBERTY CAPTURED BY SECURITY}

In his first major work, Elements of Law, ${ }^{12}$ Thomas Hobbes saw liberty in fairly simplistic terms as a capacity to act or to forbear from acting, which capacity leads naturally to deliberation as between rival paths (should I go with my appetites or let my fears triumph?), which in turn produces a decision, the will to act or not to act as the case may be. What is marvellous about this, and for its day highly original, is how it relegates reason to a sideshow to the main event, which is all about emotions - feelings, wants, aversions, and so on. In this world of 'blameless liberty', we naturally desire what is good for us and seek to avoid what is bad for us: and above all for Hobbes this entails fleeing from death. As Quentin Skinner puts it in his recent book Hobbes and Republican Liberty, it was for Hobbes obvious that ' $[\mathrm{w}] \mathrm{e}$ have a natural tendency...to do everything we can to preserve our lives'. ${ }^{13}$ Because this disposition is so very reasonable, we must furthermore have the natural right to act to preserve ourselves at all costs. The last phrase is of course the rub: there is not enough of the world to go round, and there are too many of us all exercising our natural right to do whatever we want at the same time for us all to be able to be simultaneously satisfied. Consequently, in Hobbes's famous phrase, the life of man is 'solitary, poor, nasty, brutish, and

\footnotetext{
${ }^{11}$ In what follows, I have been very influenced by the work of Quentin Skinner: see most recently his Hobbes and Republican Liberty (Cambridge University Press: Cambridge, 2008).

${ }^{12}$ T. Hobbes. The Elements of Law Natural and Politic (1640, in F. Tonnies (ed), London: Simpkin, Marshall, and Co., 2nd ed, 1889).

13 n 11 above, 36.
} 
short.'14 To quote Skinner again, '[t]he desperate paradox on which Hobbes's political theory is grounded is that the greatest enemy of human nature is human nature itself.' 15

The way out of this conundrum lies in obliging ourselves to forbear from acting according to our will and power. This requires submission to a sovereign to whom we are henceforth to be 'as absolutely subject...as is a child to the father, or a slave to the master in the state of nature'. ${ }^{16}$ Because liberty is impossible, our submission to the protective force of the sovereign is practically absolute: true, Hobbes does have some sense of inalienable rights, but these do not figure prominently in his thinking, and he never seriously contemplated any kind of right of revolution against an iniquitous sovereign. His description of his later book Leviathan ${ }^{17}$ as 'a work that now fights on behalf of all kings and all who, under whatever name, hold regal rights' 18 stands as a description of the author as well as of much of his output.

Hobbes completed Elements in 1640, after which his anthem to sovereign power was rather undermined by facts on the ground, with Charles I being drawn into an escalating political and then military confrontation with Parliament. At the first hint of such trouble, in November 1640, Hobbes bolted. His destination was the France of Cardinal Richelieu and the Bourbon kings - where his comforting views were no doubt regarded as more than making up for his non-Catholicity. As the 1640s progressed, it became increasingly obvious that Hobbes's version of liberty was falling entirely out of kilter with the republican ideals of the progressive forces that were pushing their way to power in England. On their account, liberty was tied up not with what you were able or not able to do but with the sort of society in which you lived: if the governing regime was despotic, you were unfree, and this was the case, however unimpeded you were so far as day-to-day movement was concerned. Liberty was about living in a free state; without such freedom, the practice of your conduct was bound to be so cautious and so dependent on the power of others as to be effectively a life of servitude.

From his secure base abroad, Hobbes took this view on directly, first in De Cive $^{19}$ and then most famously of all in Leviathan. Far from everything depending on how a country was governed, a 'free-man is he, that in those things, which by his strength and wit he is able to do, is not hindered to do what he has a will to do'. ${ }^{20}$ If I choose not to do something merely because I dread the consequences,

14 T. Hobbes, Leviathan, The Matter, Forme and Power of a Common Wealth Ecclesiasticall and Civil (1651, in R. Tuck (ed), Leviathan: Revised Student Edition, Cambridge: Cambridge University Press, 1991), ch 13, end of para 9 .

$15 \mathrm{n} 11$ above, 42. I think that Hobbes was right to think about human nature as fundamental, but wrong about how he saw human nature - but that is an entirely different paper.

16 Hobbes, n 12 above, 20.16, 115, cited in Skinner, n 11 above, 55.

17 Hobbes, n 14 above.

18 Quoted in Skinner, n 11 above, 126, n 9.

19 T. Hobbes, De Cive (1642, Oxford: Clarendon Press, Eng tr, 1983).

${ }^{20}$ Hobbes, n 14 above, ch 21, 146, cited in Skinner, n 11 above, $151 \mathrm{n} 96$. 
this does not mean that I am not free to do it; it merely means I do not want to, that is I am still free. Hobbes defines external impediments very narrowly, therefore broadening the range of freedom - we are free even if we live in a despotic country, cannot afford to eat and feel we have to comply with damaging laws for fear of vicious punishment. This version of individual liberty fits well with Hobbes's grand scheme of liberty-disavowal, developed in Elements and restated in his later work, because it is largely residual. The few inalienable rights apart (on which, as noted above, Hobbes is not very clear in any event), we are free only insofar as we are not stopped from doing something, and the sovereign's judgment as to when and who to stop can never be contradicted. In particular, what the sovereign does in the name of security goes, and goes without saying, so if it requires that a person be impeded by the force of the state's jailors, then that is simply that - and if he (or she) obeys the law merely because of a wish to avoid this unpleasant eventuality, then such a person remains free even then, choosing to obey a law not counting as an external impediment to liberty.

Merely to state the theory in this bald way is to seem to underline the depth of Hobbes's defeat as an important and influential thinker. The collapse of the royal forces of Charles I, followed shortly afterwards by the failure of the Commonwealth that succeeded him, led to a move to the 'balanced constitution' of Charles II, which from 1660 quite explicitly resiled from the absolutism of predecessor regimes. After 1688, the idea of representative government was to take increasing hold, with the democratisation process from 1688 to 1948 gradually turning what had by now become the United Kingdom into a republic in substance if not in form. With popular government came a new sense of 'security', one which combined resistance to external threats with a new solicitude for the people. This is when the broadest of the understandings of security referred to at the start of this Paper began to come into play. Starting in Bismarck's Germany in the 19th century, and gradually spreading to the rest of the democratic world, the description of a 'welfare' (as opposed to 'warfare') state appears first to have been used by Archbishop William Temple during the second world war. ${ }^{21}$ At the same time, in the US, President Roosevelt was reconfiguring the idea of freedom to include not only 'freedom from fear' but also 'freedom from want', by which the president meant 'economic understandings which will secure to every nation a healthy peacetime life for its inhabitants'. ${ }^{22}$ In the postwar world of civil and political, but also economic, social, and cultural human rights, it was not Hobbes's vision which appeared to have triumphed, but that of the Levellers, the quickly marginalised group of radicals or 'rebels of the present time' as Hobbes called them, ${ }^{23}$ who had tried so hard (but unsuccessfully) to keep

21 See J. Kent, William Temple. Church, State and Society in Britain 1880-1950 (Cambridge: Cambridge University Press, 1992).

$22<$ http://docs.fdrlibrary.marist.edu/4free.html $>$ (last visited 30 November 2009).

23 Skinner, n 11 above, 154. 
the Cromwellian revolution on a Republican or (as we might say today) democratic trajectory. ${ }^{24}$

And yet, despite it all, Hobbes's subjugation of liberty to security is not the minor footnote to a lost authoritarian era that it deserves to be. Skinner ends his recent study by admitting that in Hobbes's 'assault on the republican theory of liberty...we can hardly fail to acknowledge that he won the battle'.25 While this may be perhaps overstating things a little, there is no doubt that Hobbes remains hugely influential. How can this be?

The first point to make by way of an answer is to notice how in Britain, and indeed perhaps even generally, the republican victory has been less complete than the universal democratic narrative would have us suppose. This is not just about form, though of course the United Kingdom does remain distinctly nonrepublican in its retention of the monarchy, and at least some other democratic states find themselves applauding by their vote members of the families of earlier elected rulers (such as President George W. Bush, for example, or Prime Minister Lee Hsien Loong in Singapore). Though the vote has been conceded, and participation in the governing of the state guaranteed to all but the entirely incompetent, ${ }^{26}$ this has not produced the renaissance of the free-born citizen that many proponents of the vote (nostalgic for a magically unlived past in antiquity perhaps) may have assumed would inevitably follow. The power of private money, the systemic defects in the prevailing constitutional order, the conservative tendencies of the state bureaucracy, the lure of populist nationalism, the temptation to indulge in a rhetoric of fear, and the lack of energetic engagement in self-governance revealed by many citizens have all combined, with other factors no doubt, to debilitate the operation in practice of the republican/democratic form of government. Our republican freedom remains under-expressed in democratic society, and even when it emerges its flourishing is often stunted by anxiety. There is something, too, in Hobbes's appeal to human nature and his denial of the perfectibility of man that has surely played a part in his continuing appeal, particularly against more (complacently?) idealistic visions of the human an optimism that appears to have died out with democratic socialism.

Secondly, Hobbes's residual theory of liberty has proved of immense influence. In particular, it has underpinned a strong libertarian streak in AngloAmerican culture and law. This has been particularly amongst those whose fortuitously disproportionate access to wealth (not nearly so challenged as might have been the case had the transition to republican equality been fully made) gives them much greater opportunity than the less advantaged for action designed to

${ }^{24}$ M. Loughlin, 'The Constitutional Thought of the Levellers' (2007) 60 Current Legal Problems 1.

25 Skinner, n 11 above, 216. The very last sentence, immediately following this, is, 'But it is still worth asking if he won the argument'.

26 Apart from the continued exclusion of prisoners in a number of countries, including the UK, though the matter is currently under review in this jurisdiction, as required by the adverse Strasbourg ruling in Hirst v United Kingdom (No 2) [2005] 42 EHRR 849. 
fulfil their own personal goals, self-improving conduct in which they (as Hobbes would say naturally) desire to engage untrammelled by the state. It is only a slight exaggeration to say that this brand of libertarianism appears to have embedded itself in (particularly) English culture to a very deep degree indeed. As we have seen, Hobbes's theory requires that liberty be both extensive (in this residual sense of being the presumptive position) and at the same time vulnerable to aggressive state action, capable of being smashed if Leviathan judges such repressive action to be essential to the safety of the state. It has been in English law that the residual theory of liberty, promoted by Dicey in the $19^{\text {th }}$ century, ${ }^{27}$ has really bedded down, enjoying to this day an eminence in constitutional law teaching that is only being very slowly eroded by the move to rights.

With this observation we come to the central point: Hobbes's combination of an outlandishly extreme commitment to individual freedom on the one hand, with a deep precariousness so far as the protection of such liberty is concerned, is a third - and key - reason why he has proved so enduringly popular. Such an approach to freedom is only unsatisfactory if you experience it as precarious, if the contingent nature of the exercise of your freedom is before you all the time. If it is not, if Leviathan rarely intrudes on you, your family, or your immediate community, in other words the people you know, then the fragility inherent in your liberty is not to the foreground of your thinking. It is the freedom you experience, not the ease with which it is taken away. The latter may be something that others suffer - alleged revolutionaries, suspected 'terrorists', fifth-columnists, foreigners who seek to subvert the state from within - but because they are not you or like you, their vulnerability does not register. In designing a system which turns everything over to Leviathan, while assuring the majority that Leviathan will not challenge their freedom to pursue their individual appetites as they wish as long as they do not rock the boat, Hobbes produced an artifice which has remained attractive long after the monarchs and despots for whom he argued have slunk from centre stage. It has endured, moreover, right into the democratic era, a time when - perhaps for the reason given earlier as the first explanation of Hobbes's enduring influence - servitude may have disappeared, but a recognisably Hobbesian apolitical, selfish passivity (the pursuit of individualist desires) has, if anything, - fuelled by its compatibility with capitalist modes of thought - come even further into prominence.

This last observation is tied up with the fourth reason for Hobbes's enduring influence, which is the attractiveness to all those in power - whatever the source of their political legitimacy - of his heightened sensitivity to the need for security. We are back to thinking through the consequences of Hobbes's grasp of the power of human nature and his deep awareness of the power of feelings as a motive for action. In the state of nature, insecurity was of course rooted in the absence of government, but the state of nature itself was something of a fabrication

27 A.V. Dicey, Lectures Introductory to a Study of the Law of the Constitution (London: Macmillan, 2nd ed, 1885). As my colleague Paul Kelly has pointed out to me, Bentham's strong critique of Hobbes was also in part responsible for his revival in the $19^{\text {th }}$ century. 
- Hobbes occasionally mused about the America of his day being in a state of nature or Germany long ago, ${ }^{28}$ but he was never serious about pinning it down as an empirically-grounded phenomenon. Indeed, commenting on republican theories which celebrated free states, he pretended to believe that this must have been a reference to a state of nature not within a society, but on a global scale, nation against nation, state against state. ${ }^{29}$ A theory so dominated by security concerns was bound to make easier actions by state authorities to preserve the state, after the establishment of Leviathan, from both external and internal threat; the spectre of a return to the disaster of the 'solitary, poor, nasty, brutish and short' life would also be before the authorities who had read their Hobbes: the raison d'etre of Leviathan being security, action to defend security became second nature. As time went on, such defence was increasingly against the 'other' within the culture as well as the 'other' without. This is not to say that Hobbes caused government actors to behave in a certain way. But his well-known vision of the government of a state as the location of absolute sovereignty, of power the exercise of which could not be gainsaid by those subject to it, was inevitably agreeable to those who, in subsequent generations, were to feel the need to act against a variety of perceived threats to the security of the state. Hobbes provides an important backdrop to the attacks on liberty in the name of security that have been such a feature of the democratic era, supplying that thread to the discussion which says security matters above all and (recalling our second point above) that security does not infringe liberty: that not only are those who do not notice repressive laws free, but so too are those coerced by fear into sullen obedience.

Important though he is, however, Hobbes could not have pulled all this off by himself. This is where the imperfect triumph of republican thought needs to be noted once again, for another feature of its incompleteness (related to the theory itself as much as its realisation) was its failure to think through properly what individual liberty in a free state entailed as a matter of personal (as opposed to societal) freedom. Perhaps (as I shall argue at the conclusion of this paper) the lack is in any language of what we would today call 'human rights', a framework for resisting particular state action against individuals other than in defined and defensible circumstances (though, as we shall also see presently that approach contains its own vulnerabilities). Whether or not this is the case, it is clear that republican thought emphasises the security of the (free) state in a way that it might not be an exaggeration to say reads as practically Hobbesian in the blank cheque it gives to authority, albeit this time a different kind of authority, republican rather than despotic. The important point here is not about whether a state has a right to defend itself - of course it does - but what controls there are on those whose responsibility it is to determine whether a challenge exists, and if so what needs to be done to meet it. In the republican version of a free state, such matters are too

${ }^{28}$ See Skinner, n 11 above, 98.

29 ibid, 175-177. 
often left to a single actor without further accountability. Even that great republican figure John Milton was unabashed in his willingness to act against Catholics, but also (more seriously from the perspective of this essay) to clamp down on sedition (while of course it is acknowledged objecting to controls on publication in advance). ${ }^{30}$ Thus the British judges were able consistently to support draconian state action through the democratic $20^{\text {th }}$ century, preying in aid of their argument the kind of pithy piece of rhetoric so memorably deployed by Darling $\mathrm{J}$. in the course of one case under the defence of the realm regulations, that laws such as the one before the court needed to 'be construed according to the maxim salus populi, surpema lex'. ${ }^{31}$ This was a republican as well as a Hobbesian position to take.

\section{THE TAMING OF LIBERTY}

These various Hobbesian and republican supports for security over liberty, bolstered by the fragility of the residual theory of liberty (albeit fragile, as we have seen, only to those who seek change), are evident in the struggle for freedom that is played out over the series of conflicts that mark first the emergence and then the maintenance of the democratic era. Thus in 1765, in the famous decision of Entick $\mathrm{v}$ Carrington, ${ }^{32}$ the chief justice Lord Camden led his fellow judges in denying government the power to act as it wished against a political opponent on an asserted principle of 'state necessity', with the court condemning the impugned government action as unlawful because ungrounded in law. For present purposes, what is interesting about the case is that while the basis for the denial of the power that was sought to be exercised - a right of entry and seizure of papers - was the continuing right to property enjoyed by John Entick (expressed in terms redolent of John Locke as 'the great end for which men entered into society' having been 'to secure their property'), this was not an absolute right, but was rather one 'which is preserved sacred and incommunicable in all instances where it has not been taken away or abridged by some public law for the good of the whole'.33 Thus in proper Hobbesian fashion, the right to property did not precede law; though expressed in the judgment in positive terms, it was in fact residual. The issue in the case was not the invasion of the right to property as such; rather it was

\footnotetext{
${ }^{30}$ See J. Milton, Areopagitica (Speech to the Parliament of England, 1644).

31 Michaels v Block [1918] 34 TLR 438. More famous or notorious cases along similar lines include R v Halliday [1917] 2 AC 260, Liversidge v Anderson [1942] AC 206 and Chandler v Director of Public Prosecutions [1964] AC 763. See generally, K.D. Ewing and C.A. Gearty, The Struggle for Civil Liberties. Political Freedom and the Rule of Law in Britain, 1914-45 (Oxford: Oxford University Press, 2000). One of the majority judges in Liversidge, Lord Wright, explains the case along these lines in his 'Liberty and the Common Law' (1945-7) 9 CLJ 2.

32 [1765] 19 St Tr 1030.

33 ibid, [1066] (emphasis added).
} 
the absence of a legal basis for the infringement. Leviathan had not spoken properly, that was all.

The repression in England that followed the French revolution in 1789, and in particular the extremist turn taken after the execution of the French king, confirmed the power of law to override liberty in the name of security. The crackdown by the Pitt government was underpinned by a plethora of statutes and was largely unquestioned in court. ${ }^{34}$ When eventually the United Kingdom escaped the shadow of France and commenced its slow journey to democracy (commencing with the Great Reform Act of 1832), the idea of rights retained by the individual which could stand up to positive law had faded away, ${ }^{35}$ with it being during this period that the unquestioned sovereignty of parliament came to be conclusively established in the courts ${ }^{36}$ (albeit without questioning what, for present purposes, is an important survival from the pre-legislative era, namely the extra-statutory right of the executive to act to preserve the security of the realm under the ancient common law -ie judge-made - power to act to keep the peace).

By the end of the 19th century, it is clear that Hobbes's security-state with a residual model of liberty, but without any strong notion of pre-political inalienable rights, is firmly in place: in 1885, the high priest of Victorian constitutionalism Albert Venn Dicey was able to write confidently about there being no rights in the English system at all but rather a series of freedoms that existed because all were free unless the state (whether under statute or the common law) had acted to control their liberty. ${ }^{37}$ In deducing from this that England was a free society, Dicey was making an assumption about non-intervention which may have been true of him and his milieu, but which was distinctly untrue about whole categories of persons (trade unionists, women in search of the vote, Irish nationalists) of whom Dicey either knew very little or whose causes he deplored. ${ }^{38}$ The pattern set in the last decades of the nineteenth century subsisted until right through to the end of the $20^{\text {th }}$. For the bulk of the population, freedom was evident in the ease with which they went about their daily lives: there was no difference between the quality of the various kinds of acts that an individual desired to do - it might be shopping, sight-seeing, or queuing for theatre tickets - or it might be attending a political meeting with a view to seeking a particular reform, or engaging in a mass demonstration. The law did not distinguish between any of these, much less attach greater importance to the political over the apolitical. Though all were in theory equally vulnerable to the intervention of Leviathan (expressed either through

\footnotetext{
34 A good historical record is still E. P. Thompson, The Making of the English Working Class (London: Victor Gollancz, 1963).

35 See J. Goldsworthy, The Sovereignty of Parliament (Oxford: Clarendon Press, 1999).

36 See such cases as Edinburgh and Dalkeith Railway v Wauchope [1842] $8 \mathrm{Cl} \& \mathrm{~F} 710$ and Lee v Bude and Torrington railway Company [1871] LR 6 CP 576.

${ }^{37}$ Dicey, n 27 above.

38 An example of his approach to one of these communities, the Irish nationalists, can be seen by perusing his brilliant polemic, England's Case Against Home Rule (1886), available from

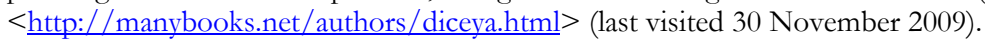


statute or via the common law), in practice only those who challenged power were made the victims of state coercion.

Above all, what this meant in the $20^{\text {th }}$ century was that individuals and associations of Communist-inclined, radically socialist and/or strong syndicalist views were consistently the victims of the 'Iron heel' of state power, ${ }^{39}$ in a way that was at all times perceived by those doing the coercing as not raising any general questions of liberty at all. The prosecution of leading members of the Communist Party for sedition in 1925 was regarded by the Home Secretary of the day, William Joynson-Hicks, as entirely compatible with his own commitment to liberty and freedom because what the accused persons had been engaged in was not an exercise in 'the right type of freedom of speech', which was the sort not calculated 'to damage the Constitution'. 40 When lawyers sought to challenge a police ban on public meetings outside unemployment exchanges during the Depression years, the Chief Justice Lord Hewart began his ex tempore judgment upholding the conviction of the protestors by volunteering that he could not see how the case raised any issues of civil liberties at all. ${ }^{41}$ This was the very same man whose book savaging the inroads on liberty made by the emerging welfare state, The New Despotism, had been such a publishing sensation within the professions in 1929.42 The two positions made perfect sense from a Hobbesian perspective. The second was about the freedom of people like Lord Hewart (or at least the sort of person he had become, having himself been born in fairly modest circumstances as the son of a draper ${ }^{43}$ ) who merely wanted to enjoy what their wealth gave them the freedom to do without interference from the state, while the first was about controlling the disruptive capacities of a radicalised rabble. In 1959, the power to use large-scale picketing to support trade union goals in industrial disputes was severely limited by a judicial ruling which effectively upheld a police limit of six on the number of those picketing at any one time, a condition imposed under the ancient common law power to act to prevent breaches of the peace. ${ }^{44}$ Once again, the judges were simply oblivious of any civil libertarian dimension to the issue before them: the successful reception of Hobbesian thought into the mainstream of English law had equipped them with an impaired vision of the facts before them so deeply rooted that they were unaware they were wearing blinkers.

Would a written bill of individual rights have stopped this Hobbesian/republican juggernaut in its tracks? As we have seen, the idea of fundamental rights had drifted from law to rhetoric with the failure of the revolution of 1689 to embed natural or fundamental rights above legislative action. Had it been enacted (an impossibility for its day, it is of course acknowledged), a document along the lines of the US constitutional amendments of a century later

39 J. London, The Iron Heel (London: Macmillan, 1908) - My thanks to Keith Ewing for drawing this excellent book to my attention.

${ }^{40}$ The story is in Ewing and Gearty, n 31 above, 136-151, quoted remarks at 148.

${ }^{41}$ Duncan v Jones [1936] 1 KB 218, esp [221]-[222].

42 London: Ernest Benn Ltd, 1929.

${ }^{43}$ My thanks to Neil Duxbury for this biographical information.

44 Piddington $\mathrm{v}$ Bates [1960] 3 All ER 660. 
might be thought to have had the potential to have given the republican model of freedom greater bite in particular (ie individual) cases, by forcing state actors to justify their actions to the people and to other organs of the state by reference to general values (free speech, freedom of assembly, etc) when, if they had not had such a bill, they might well have been able simply to deny that any such issue was engaged. I shall return to a fuller argument along these lines later. For now, it is sufficient to note that the question raised is from the historical perspective that we are taking at this point essentially an empirical one and applicable to the United States directly (from its inception) and the United Kingdom in three phases: very indirectly from 1953 (when the European Convention on Human Rights and Fundamental Freedoms came into force), less indirectly from 1966 (when individuals were allowed for the first time to take the UK government to the European Court of Human Rights for alleged breaches of their rights), and partially from 2000 (when implementation of the Human Rights Act 1998 has meant that all but sovereign acts of the legislature can be challenged for breach of most of the rights in the Convention). There will be more on the third phase at a later point in this paper. So far as the first two phases of European Convention involvement is concerned, the cold war cases that reached its judicial authorities did not tend to be successful: neither the applicants in the GCHQ case nor the members of the German Communist Party were able to persuade the Strasbourg authorities that their cases were even worth hearing. ${ }^{45}$ Nor was the challenge to the UK media ban, imposed in 1988 on Sinn Fein and supporters of its political goals, thought sufficiently serious by the European agencies to be even allowed to reach the full court. ${ }^{46}$

So far as the US is concerned, despite some pointers the other way during the brief liberal turn of the Supreme Court during the 1960s and early 1970s, the overall American experience is of the incorporation of the rights in its bill of rights into a Hobbesian/republican security-agenda, whereby they have become a means of legitimising restrictions in individual cases rather than of stopping such infringements in their tracks. It is clear from the record that the capacity of radical socialist and/or Communist Party speakers to get any kind of public platform was invariably allowed by the judges to be truncated by coercive state action, effected within the framework of free speech, for which of course the constitution notionally provided. So we see Eugene Debs's conviction for obstructing the recruitment of men to fight in the First World War (by declaring his abhorrence of war and of the rich) upheld in 191947 and those of his fellow radicals, Jacob Abrams and Anita Whitney, in 1919 and 1927 respectively.48 The Joynson-Hicks moment came for the United States in the well-known Dennis v

45 Respectively Council of Civil Service Unions v United Kingdom [1988] 10 EHRR 269 and German Communist

Party Case [1957] 1 Yearbook of the European Convention on Human Rights 222.

46 Brind v United Kingdom [1995] 18 EHRR CD 76.

47 Debs v United States 249 US 2111 (1919).

48 Abrams v United States 250 US 616 (1919); Whitney v California 274 US 357 (1927). 
United States decision in 1951.49 In this case, the Supreme Court upheld the legitimacy of the use of the Smith Act to clamp down on Communist speech, and in so doing signalled the law's effective collusion in the McCarthyite scare that was just then beginning to build up a dangerous momentum. Writing for the majority, Mr Justice Frankfurter explained that the outcome for which the defendants worked was so extreme in its consequences that it justified the restrictions on speech to which these potential destroyers of America's way of life were being required to adhere. (Indeed, while it had been underpinning such breaches of liberty (of expression) in the name of security (from left-wing thought), the Supreme Court was also developing a habit of using the idea of liberty (of contract) to destroy progressive legislation aimed at achieving security against want - this phase of reactionary conservatism, known (after one of the key early cases) as 'Lochnerism', only came to an end in the political turmoil sparked off by President Roosevelt's plan to swamp the court with his own appointees in 193637. But the conservative tilt on issues of national security lasted longer, arguably into the early 1960s.)

To sum up: by the end of the cold war, the United Kingdom and the United States combined a commitment to liberty which allowed most people to do more or less what they wanted most of the time with an approach to security which allowed the state to crack down hard on those judged to be challenging the established political order, whether from within or without. The latter such state action could have the effect of savagely truncating the freedoms of those against whom the state moved in this way, and indeed was often designed specifically to do exactly that, but despite this there was no insistence on any kind of effective accountability on the part of the state actors engaged in such acts of repression. What oversight there was tended to be purely symbolic, not designed to have any kind of awkwardly restraining impact on those exercising such power. Hobbesian and republican theory combined to explain such repression as either necessary to prevent (a return to) anarchy (Hobbes) or as essential to preserve the liberty of the state (republican). Sometimes the two accounts merged into each other. But whether singularly or in combination, they explained - to the state servants engaged in the crackdowns; to the political leaders who justified them; to the free people who listened to such rationalisations; to the judges who might from time to time be asked to uphold such exercises of power without asking too many questions - why it was that such apparent autocracy (not to put too fine a point on it, such selective despotism) was in fact mandated by liberty rather than subversive of it. The existence of a guaranteed set of rights, to which supposedly individuals caught up in repression of this sort could turn, made no difference to the state, functioning if they had any impact at all as a further legitimisation of the restrictions being imposed.

49 Dennis v United States 341 US 494 (1951). 


\section{SECURITY TRIUMPHANT?}

The attacks of 11 September 2001, and in particular the reaction they provoked from the then US Administration of George W. Bush, greatly exacerbated the Hobbesian and republican complementarity between liberty and security that I have been discussing in this essay. First, and most obviously, the Al Qaida actions were a shocking reminder to Americans of the importance of the role of government in maintaining security - while there was great cooperation among individuals in the few days following the attack, the 'state of nature' seemed closer than anyone might have supposed possible as Manhattan lay cut-off from the rest of the country, all flights remained grounded, and the president sought advice on when to come out of hiding. The threat came both from without (the Al-Qaida organisation) and from within (Al-Qaida fifth columnists pretending to be ordinary residents), with each of these aspects of the security challenge seeming to need to be addressed if (and at the time this would not have been felt an exaggeration) the state of nature were not to return, brought back to life by some imminent, horrendous nuclear attack or other devastating blow.

The effect of all this was that, secondly, the executive branch of the state felt emboldened to seize total responsibility for security, to assume the role of Leviathan for the duration of what it quickly began to describe as 'the war on terror'. With perfect Hobbesian consistency, this involved actions that were either directly illegal - such as the rendition of suspects to places where they faced the likelihood of death and/or torture and the wiretapping of electronic traffic without congressional approval ${ }^{50}$ - or of barely credible/merely asserted legality examples would include the detention of 'unlawful combatants' at Guantanamo, Abu Ghraib, and similar sites and the assertion that particular forms of maltreatment of prisoners did not fall within international or national prohibitions on torture and were therefore not illegal. This newly invigorated Leviathan also used more formal, that is to say traditional, means of exercising its power such as the deployment of well-established immigration law against suspects and the enactment of the Patriot Act via the usual constitutional channels in Autumn 2001. But in the minds of those in charge of Leviathan at this time, such reliance on formal law was more a tactic of choice than an imperative driven by the demands of the rule of law. With its shared concern to protect freedom with whatever actions were judged to be necessary, the republican model of government had few intellectual defences against this barrage of executive power.

We are now close to understanding how President Bush could have spoken as he did at his second inauguration in January 2005. For a third consequence of the attacks of 11 September 2001 was to give even greater prominence to the kind of perspective on liberty (and on human rights for that matter) which could without

\footnotetext{
${ }^{50}$ See generally, J.J. Paust, Beyond the Law. The Bush Administration's Unlawful Responses to the 'War' on Terror (Cambridge: Cambridge University Press, 2007).
} 
contradiction view these terms as reflective of the values of a particular kind of free and democratic society rather than as words signifying the guarantee of specific freedoms and rights to every individual within such a society. The Hobbesian tendency to promote an enduring sense of liberty among the majority while destroying it for those engaged in (or suspected of being engaged in) subversive work is very much in point here. As Ronald Dworkin has said of the Bush Administration's response to 11 September:

None of [its] decisions and proposals will affect more than a tiny number of American citizens: almost none of us will be indefinitely detained for minor violations or offences, or have our houses searched without our knowledge, or find ourselves brought before military tribunals on grave charges carrying the death penalty. Most of us pay almost nothing in personal freedom when such measures are used against those the President suspects of terrorism. ${ }^{51}$

When the President spoke of liberty during his address, he was speaking directly to the great number of Americans who felt free in their personal lives, but who also felt that this freedom was being challenged by outsiders, enemies of their community and of their way of life. Their belief in liberty did not extend to the point where they could express any kind of solicitude for those whose liberty was being destroyed by the government in the interests of security. This did not mean they were opposed to liberty or incoherent in their support for it - it meant merely that according to their understanding of the term its selective application in this way was entirely to be expected.

A fourth consequence of the attacks of 11 September has been to give a strong impetus to the spread across the world of the approach to liberty and security that we have just identified. In this paper, I have limited the discussion to the English/British and the American stories of liberty and security. But the reconfiguration of the world that has taken place after the end of the cold war has produced a post-totalitarian model of governance which combines the delivery of freedom, in the Hobbesian sense of being able to act without external impediments, with a concern for security which underpins, indeed legitimises, strong state action against minority groups and other dissenting individuals whose views do not fit with those of the state. ${ }^{52}$ Interestingly, this model is to be found in both continuing communist and newly democratic states, China being the large example of the first and Russia of the second. The rulers of these and other similarly constituted countries, whether clothed in a democratic veneer or not, are the modern version of those 'kings and all who, under whatever name, hold regal

\footnotetext{
${ }^{51}$ R. Dworkin, 'The Threat to Patriotism' (2002) 49 New York Review of Books No 3 (28 February 2002).

52 See the depressing e-bulletins on counter-terrorism and human rights issued by the International Commission of Jurists detailing the global nature of the shift to counter-terrorism law since the attacks of 11 September: <http://www.icj.org/> (last visited 30 November 2009). The November 2009 bulletin can be accessed at <http://www.icj.org/IMG/E-Bulletin-Nov09-Final.pdf> (last visited 30 November 2009).
} 
rights'53 for whom Hobbes acknowledged he was an avid champion. Such a framework works very well for the beneficiaries of new capitalist modes of production in these post-totalitarian states - their liberty to spend is untrammelled by any desire to challenge the system from which they are gaining such advantage. The plethora of laws (and extra-legal powers) that can be and are readily invoked to destroy those who step out of line do not disturb the sense of personal freedom enjoyed by the majority.

\section{A HUMAN RIGHTS APPROACH TO LIBERTY AND SECURITY}

So far in this essay, I have criticised Hobbes's approach to liberty and security as being too broad and mechanistic in its definition of liberty, and consequently as too ready to allow the jettisoning of freedom in the name of security. The republican approach which I have described as an alternative to Hobbes is better on the link it makes between personal and political freedom, but as I have argued, it has not been as deeply embedded in western political systems as might have been expected and is in any event still not very good on the accountability of state power exercised in the name of security in specific cases: in other words, it is too ready to jettison the few to save the many. In this last respect, there is, as the record discussed here shows, often little to choose between the two models when it comes to cracking down on speech and conduct with which the political leadership is out of sympathy or by which it feels threatened. So while the Hobbesian analysis does not work at all, the republican is not very much better.

Is there an approach to liberty and security which manages to posit an alternative to Hobbes, but without the limitations that I have just described in the republican model? Anticipating this question at the start of this essay, I asserted that there was a benign model which combined liberty and security in a way which drew effectively upon progressive threads in our history, and which, by avoiding the problems in each of our primary models, delivers a version of liberty and security which best suits modern conditions. Reflecting the additional dimension which it brings to the discussion, it is appropriate to designate this as the human rights model, in contradistinction to the Hobbesian and republican approaches that have already been outlined. Of course, Hobbes was, as we have seen, on to the human rights theme, but his evocation of it served only to provide a platform for the effective obliteration of such rights in the name of security. John Locke's idea of natural rights was originally of a more resilient character, but his rights never embedded themselves in England (and afterwards Britain), buckling before the sovereign power of the gradually democratising legislative branch of

53 n 18 above. 
government. ${ }^{54}$ In the United States, the language of human rights disappeared with the movement to constitutional rights which followed the adoption of the succession of rights amendments to the US constitution in the early 1790s - from this time on, rights analysis in the US becomes far more an issue of domestic law than of emancipatory politics.

The shape of a modern, human-rights-based approach to liberty and security does have distant roots, albeit these are not those that have grown from seeds thrown down by Hobbes and Locke. Martin Loughlin has convincingly demonstrated, for example, that much of the Leveller's agenda of the 1640s can, without too much difficulty, be recast as a human rights manifesto with quite a contemporary ring. ${ }^{55}$ This takes us back to the broader meaning of security which was mentioned at the start of the essay and then again when we were discussing the move to democratisation in Europe and the US. Particularly resonant with meaning for today is President Franklin Roosevelt's famous commitment to the four freedoms, to speech and expression and to religion on the one hand, and from want and from fear on the other. ${ }^{56}$ After the conclusion of the war, which had provided the urgent context for these remarks, their meaning was unpacked into the rights-language of the universal declaration of human rights, becoming in the process a central plank in the then newly emerging world order. In the immediate aftermath of the end of the cold war, the human security movement that emerged in the 1990s was also inspired by the idea of human rights, seeing in it a means of pushing ahead with individual rights, but also as delivering the kind of secure environment which is necessary for any such rights to be enjoyed. These are the forbearers of our contemporary understanding of human rights as a term that can provide an effective bridge between liberty and security. They are reflected in the inaugural address of President Barack Obama on 20 January 2009 when he rejected as 'false the choice between our safety and our ideals', going on to assert that the founders of the United States, when 'faced with perils that we can scarcely imagine, drafted a charter to assure the rule of law and the rights of man - a charter expanded by the blood of generations. Those ideals still light the world, and we will not give them up for expedience sake. ${ }^{57}$

So what then does this human rights approach entail? The initial resemblance is with the republican model. The importance of political rights in the modern human rights tradition reflects the underlying commitment of the human rights perspective to democratic forms of governance. This is what makes sense of the basic right to participate in government in both the Universal Declaration of Human Rights (UDHR) and the International Covenant on Civil

\footnotetext{
54 See D. Ivison, Rights (Stocksfield: Acumen, 2008), ch 3 for a good treatment of Locke and the antagonism to natural rights that his writings were later to provoke.

${ }^{55}$ Loughlin, $\mathrm{n} 24$ above.

${ }^{56}$ Roosevelt, $\mathrm{n} 22$ above.

57 At < http://www.whitehouse.gov/the press_office/President_Barack_Obamas_Inaugural_Address $>$ (last visited 30 November 2009).
} 
and Political Rights (ICCPR), 58 and the various freedoms in both the UDHR, 59 and the ICCPR, ${ }^{60}$ designed to ensure open political debate. In regional documents such as the European Convention on Human Rights and Fundamental Freedoms (ECHR), where there was no historic need in drafting the document to cast the human rights net wide enough to draw non-democratic states within it, this democratic dimension is quite explicit. ${ }^{61}$

The republican model is also reflected in the degree to which a human rights approach to freedom does not require a state to embrace pacifism, to surrender any capacity to act where its survival, or security, is at stake. Articles 15 and 17 of ECHR are a good illustration of this, the first allowing derogations from most rights in situations of public emergency, the second making clear that activities aimed at the destruction of rights cannot hide behind the rights guarantees set out in the rest of the document. The large difference with the republican approach lies in the requirement for justification: the state is required to justify both its general claims with regard to the asserted emergency the state is facing and also the need to act to the detriment of particular individuals in specific situations. Thus in the well-known Belmarsh detention case, the government's claim as to the necessity for the indefinite detention of foreign but not local suspected terrorists was rejected by the United Kingdom's most senior court. ${ }^{62}$ The incarceration of these particular individuals - made possible simply on account of their status as foreigners - was unable to jump the hurdles of rationality and of proportionality that the human rights model of analysis had erected. This focus on individual impact, regardless of the nationality, ethnicity, or popularity of the individual concerned, is what stops the human rights approach from becoming dangerously general, an empty source of values rather than a practical guide in individual cases. At bottom, it takes its lead from the ethical demand that we are all - every one of us - to be given the chance to lead fruitful lives, that regardless of who we are or where we come from, we have a worth intrinsic to our humanity.

So far as security is concerned, the human rights approach builds upon Roosevelt's insightful division that freedom is about more than civil and political rights, important though these are. There is freedom from fear for sure, and clearly this includes the kinds of anxieties about terrorism that it is said that many people have come to have about the threat of terrorist violence. The human rights answer to such fears is to design an effective criminal law system, one which

\footnotetext{
${ }^{58}$ Universal Declaration of Human Rights (1948, December 10), Art 21; International Covenant on Civil and Political Rights, G.A. res. 2200A (XXI), 21 U.N. GAOR Supp. (No. 16) at 52, entered into force Mar. 23, 1976 (U.N. Doc. A/6316 (1966), 999 U.N.T.S. 171), Art 25.

59 eg Art 18-20.

${ }^{60}$ eg Art 18-22.

${ }^{61}$ Council of Europe, Convention for the Protection of Human Rights and Fundamental Freedoms, opened for signature 4 November 1950 (ETS 5). See the perambulatory reference to an 'effective political democracy' and the qualifications on many rights which are permitted where they are judged 'necessary in a democratic society'.

62 A v Secretary of State for the Home Department [2004] UKHL 56, [2005] 2 AC 68.
} 
operates as a strong deterrent against violent wrongdoing and which endeavours to find and punish those who transgress its terms. It also invariably embraces a variety of inchoate offences (attempt, conspiracy, incitement, for example) so as to equip the authorities to act to prevent anticipated crime as well as to punish wrongdoers after the event. Such codes of law can also, with perfect consistency from a human rights perspective, design laws specifically to deal with particularly serious challenges to security - no human rights defender wants a static criminal law incapable of responding to the threats posed by technological, social, or other change.

What such a criminal law-based approach to security insists upon, however, and what distinguishes it from its republican comparator, is that those who are subject to its force are not arbitrarily or irrationally chosen, that there is some reason why the law has moved against this or that person in particular rather than against someone else. This flows from the starting premise of human rights that each of us has a personhood worth respecting simply on account of the fact of our existence in human shape. So a reasonable suspicion of a particular crime is required before a person may be arrested or their property entered or some other involuntary act is imposed on them. Before the personally catastrophic imposition of imprisonment, the criminal law insists on guilt having been established beyond reasonable doubt and only after a fair and open process of evidence evaluation, including, in many systems, a final verdict not from the bureaucrats of the law, but from ordinary lay-people (in the form of a jury). It is because of the human rights defender's enthusiasm for this criminal law approach that such a person is so distasteful of the counter-terrorism model - it pushes in the direction of wide administrative powers, of crimes so broadly defined as to be useless guides to future conduct, of trial procedures which, if they take place at all, are so truncated as to render public justice impossible of achievement. The human rights advocate dislikes all this, not because he or she refuses to allow that freedom from the fear of terrorist attack is illegitimate, but rather because such a person believes that we have available to us in the form of the criminal law an approach to the problem which is both more principled and also more effective. ${ }^{63}$

Important though freedom from this kind of fear is, the human rights model of security also insists that we do not ignore freedom from want. Security is a richer term than those concerned only with terrorism (and crime) often acknowledge. Flowing with perfect consistency from its rich reading of an ethic derived from personhood, the human rights approach emphasises as well the side to security that is to be seen in terms such as 'social security'. It does not neglect the economic and social dimensions to living, the freedom from want of which Roosevelt spoke. Rather, it sees this kind of security as a platform for the exercise of true freedom, as an essential pre-requisite of a liberty that is both universal in its reach and bountiful in its content. Its heroes are the Levellers, with their

${ }^{63}$ A very clear statement of this approach was set out by Sir Ken McDonald in the course of a lecture, 'Security and Rights' that he gave as Director of Public Prosecutions to the Criminal Bar Association on 23 January 2007. 
advanced talk of equality before the law and the relief of poverty and Roosevelt, with his new deal legislation in the early 1930s. Barack Obama's comments in the course of his inaugural address, quoted earlier, ${ }^{64}$ suggest that he, too, intuitively grasps the value of the language of human rights to a proper synthesis of liberty and security.

\section{CONCLUSION}

This paper starts with one US president's malignant synthesis of liberty and security and ends with his successor's seemingly more benign view of how the two can be brought together. Of course, there are all sorts of dangers in the language of human rights, some of which we have already encountered in this essay, but others of which we mention now for the first time - the risk that human rights law is deployed to legitimise rather than to prevent human rights abuses; the problem of the delivery of economic and social rights; the temptation that arises in practically all rights' codes for the judges to establish a 'juristocracy' over the democratically elected branches of the state; ${ }^{65}$ the use of human rights discourse to divert attention from serious questions of justice and equality; and many more. It needs to be acknowledged as well that an innovative focus on the criminal introduces us to a new set of difficulties: the breadth of some criminal laws; the vagueness of some of their terms; the fluidity and indeed vulnerability of procedural protection in the criminal field; the ever-present temptation to plunge into an emergency criminal law. But no framework of analysis in this area (or indeed in any other) is ever likely to be entirely satisfactory: the only question is as to what kind of discussion about weaknesses, loose-ends, opportunities for reform, etc does one want to have. It is suggested that the human rights approach to liberty and security raises the right issues, focuses on the key questions, and invites a conversation about freedom and security of a sort that represents real moral progress.

\footnotetext{
${ }^{64}$ Obama, $\mathrm{n} 57$ above.

${ }^{65}$ The word in quotes was used by Keith Ewing in a brilliant analysis of the subject: see K.D. Ewing, 'The Bill of Rights Debate: Democracy or Juristocracy in Britain?' in K.D. Ewing, C.A. Gearty, and B.A. Hepple (eds), Human Rights and Labour Law. Essays for Paul O'Higgins (London: Mansell, 1994), ch 7.
} 